
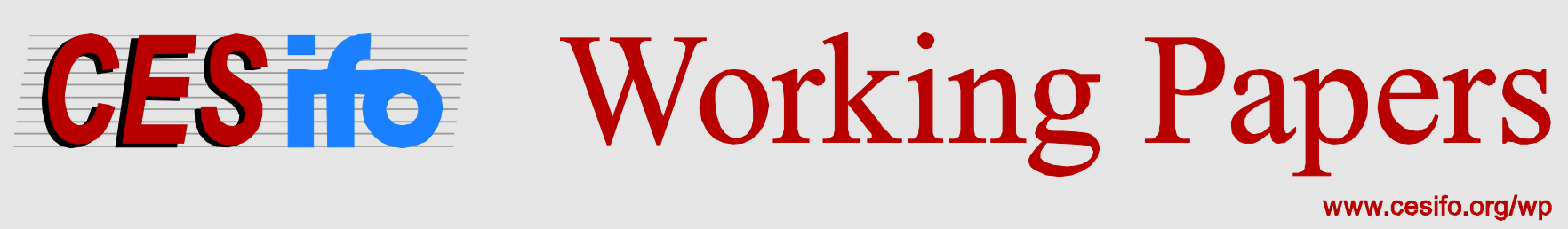

\title{
Incentive Effects of Fiscal Rules on the Finance Minister's Behaviour: Evidence from Revenue Projections in Swiss Cantons
}

\author{
Florian Chatagny
}

CESIFO WORKING PAPER NO. 5223

CATEGORY 1: Public FinANCE

FEBRUARY 2015

An electronic version of the paper may be downloaded

- from the SSRN website:

- from the RePEc website:

- from the CESifo website:

wWw.SSRN.com

www.RePEc.org

www.CESifo-group.org/wp 


\title{
Incentive Effects of Fiscal Rules on the Finance Minister's Behaviour: Evidence from Revenue Projections in Swiss Cantons
}

\begin{abstract}
Predicting available tax revenue accurately is a key step of fiscal policy. It has recently been shown that revenue projection errors have a direct impact on fiscal deficits. In this paper, we explore the relationship between the ideology of the finance minister and tax revenue projection errors, and assess how the stringency of fiscal rules alters this relationship. We use a panel dataset of 26 Swiss cantons over the period 1980-2007 as well as a new dataset of 99 finance ministers at the cantonal level. Our empirical strategy exploits the fact that the allocation of the departments - including the department of finance - to the elected politicians is a random process from the point of view of the voters. We identify a rather counter-intuitive positive effect of the ideology of the finance minister on tax revenue projection errors in the sense that a more leftwing finance minister produces relatively more conservative forecasts. We also find that fiscal rules reduce the effect of ideology on tax revenue projection errors. These results suggest that left-wing finance ministers need to curb deficits relatively more in order to signal the same level of competence to the voters than right-wing finance ministers. They also suggest that fiscal rules render the signal less informative to the voters and thereby reduce the incentive for left-wing finance ministers to be more conservative in their projections.
\end{abstract}

JEL-Code: C230, H680, H710.

Keywords: ideology, finance minister, fiscal rules, tax revenue projections.

\author{
Florian Chatagny \\ ETH Zurich \\ KOF Swiss Economic Institute \\ Leonhardstrasse 21 \\ Switzerland - 8092 Zurich \\ chatagny@kof.ethz.ch
}

I thank Marko Koethenbuerger, Peter Egger, Doina Radulescu, Federica Liberini, Randolph Luca Bruno, JanEgbert Sturm, Nils C. Soguel, Laure Athias, Yvon Rocaboy, Fabio Padovano, Marius Brülhart, Lars Feld, Christoph Schaltegger, Massimo Bordignon, Thierry Madiès, Roland Hodler, Eduardo Engel, Ronny Freier and Roland Vaubel as well as participants of the KOF Brown Bag seminar (Zurich, Switzerland), of the IDHEAP Postdoctoral conference (Lausanne, Switzerland), of the ZEW conference on Public Finance (Mannheim, Germany), of the American Public Choice Society (Charleston, USA), of the EPCS conference (Cambridge, UK), of the DEFAP Workshop in Political Economy (Milan, Italy), of the journées LAGV (Aix-en-Provence, France), of the Silvaplana Workshop in Political Economy (Switzerland), of the IIPF annual congress (Lugano, Switzerland) and of the 8th Cesifo Workshop on Political Economy (Dresden, Germany) for their useful comments. I particularly thank Lars Feld and Christoph Schaltegger for the fiscal rule index data. I am also grateful to the Swiss National Science Foundation (Grant Nr. 113587) as well as to the Institute IDHEAP for their financial and logistic support. The standard disclaimer applies. 


\section{Introduction}

The prediction and planning of major fiscal aggregates such as expenditure and revenue are key aspects of fiscal policy. Accurate projections allow fiscal policy-makers to anticipate and correct undesirable imbalances in the budget, thereby improving public finances sustainability. In that respect, accurately predicting tax revenue is a particularly central aspect of fiscal planning since it sets the amount of resources available for financing public policies. From a performance point of view, revenue projections set the limits within which expenditure must remain in order to reach fiscal balance. Recently, the dimension of fiscal projections in general, and revenue projections in particular, has attracted an increasing attention from scholars. The most recent studies have shown that political determinants such as the ideology of the government (Bischoff and Gohout, 2010), elections (Beetsma et al., 2013) or political fragmentation (Goeminne et al., 2008) are important drivers of tax revenue projection errors (TRPE). These studies suggest that policy-makers use revenue projections to influence fiscal policy and achieve their political objectives. Some authors (Goeminne et al., 2008; van der Ploeg, 2010; von Hagen, 2010) have also suggested that the finance minister may play a key role in the determination and therefore in the manipulation of revenue projections. This particular role of the finance minister in the tax revenue budgeting process has remained empirically unexplored and this paper provides a first attempt to fill in this gap.

Using a new dataset of 99 finance ministers in the Swiss cantons over the period 1980-2007, this paper explores how the personal characteristics of the finance minister, in particular his ideology, shape tax revenue prediction errors. This paper also addresses the more traditional question of the effect of budgetary institutions on fiscal outcomes. Many authors have already explored the effect of different budgetary institutions such as balanced budget rules, debt ceiling or multi-year budgeting on fiscal outcomes. ${ }^{1}$ However, little is still known about the channels through which the effect of budgetary institutions on fiscal outcomes materializes. For instance, by rendering deficits more costly, balanced budget fiscal rules are expected to create incentives that modify the behaviour of the policy-makers involved in the budgetary process. This paper addresses this aspect of fiscal policy by looking at how balanced budget fiscal rules in Swiss cantons create incentives that modify the finance minister's behaviour and eventually revenue projection errors.

In order to cleanly identify the causal effect of the ideology of the finance minister on TRPE as well as the incentive effect of fiscal rules on the ideological behaviour of the finance minister, we exploit two key aspects in the context of Swiss cantons. First, like other authors before us (Feld et al., 2011; Feld and Kirchgaessner,

\footnotetext{
${ }^{1}$ See, among others, Poterba (1994); Swank (2002); von Hagen (2010); Hallerberg et al. (2007); Bohn and Inman (1996); Milesi-Ferretti (2003); Feld and Kirchgaessner (2008); Pina and Venes (2011); Blume and Voigt (2013); Luechinger and Schaltegger (2013); Vlaicu et al. (2014)
} 
2008; Luechinger and Schaltegger, 2013), we rely on the fact that Swiss cantons have experienced a staggered introduction of balanced budget fiscal rules over time and that fiscal rules still show a strong heterogeneity across cantons in their degree of stringency. Second, in order to cleanly estimate the effect of the ideology of the finance minister on TRPE we exploit the fact that the allocation of departments within cantonal cabinets occurs in a quasi-random way from the point of view of the voters. To the best of our knowledge, this paper is the first to rely on this feature of the Swiss institutional context as an identification strategy which, together with the staggered introduction of fiscal rules, makes us confident in the causal interpretation of the results found.

The estimation of a panel data model using robust standard errors clustered at the finance minister and time level shows, rather counter-intuitively, that left-wing finance ministers produce more conservative tax revenue projections than right-wing finance ministers. Furthermore, we show that more stringent balanced budget fiscal rules tend to reduce the effect of the ideology of the finance minister on TRPE. Robustness checks suggest that this incentive effect of fiscal rules is particularly strong for left-wing finance ministers. These results are robust to alternative specification of the model as well as to different estimation methods such as system GMM and GLS with panel corrected standard errors.

These results are also consistent with the theoretical argument that, $\boldsymbol{a}$ priori, left-wing finance ministers are perceived as less competent by the voters when it comes to balancing the budget. Thus, left-wing finance ministers need to curb deficits more than their right-wing counterpart in order to signal to the voters the same level of competence and therefore need to be more conservative in their revenue projections. Balanced budget fiscal rules, by reducing deficits, make the signal less informative to the voters who attribute the lower deficits to the rule rather than to the finance minister. This creates incentives for the finance minister to engage in other types of signaling activities, and therefore reduce the incentive for the finance minister to produce conservative projections. This incentive is stronger for left-wing finance ministers since they need to compensate for the relatively negative signal sent by their ideology when it comes to balancing the budget. A policy implication of these results is that fiscal rules may be an efficient tool for reducing political manipulation of revenue projections and improve their accuracy.

This paper is structured as follows. Section 2 provides a theoretical discussion and formulates the tested empirical hypotheses. Section 3 provides a detailed presentation of the empirical background and of the data. Section 4 discusses the empirical method. Section 5 presents and discusses the results and Section 6 concludes.

\section{Theoretical considerations and testing hypotheses}

This section provides a theoretical discussion of the expected effect of the finance minister's ideology on TRPE and of how the expected effect may be altered by the incentives created by fiscal rules. Some 
testing hypotheses underlying our empirical analysis will be derived. In order to frame our argumentation, we first formulate three assumptions consistent with the context of Swiss cantons, which we believe also apply to many other countries or jurisdictions. First, we assume that underestimating tax revenue tends to reduce both expenditure and deficits. This first assumption intuitively makes sense since the amount of projected revenue usually determines the resources available to finance expenditures. Underestimated revenue projections keep expenditure at a lower level than realized revenue would. This subsequently results in a lower deficit (higher surplus) once actual revenue materializes. It has actually been shown in the context of the Swiss cantons that underestimating tax revenue by one Swiss franc per capita reduces deficit by around 0.75 Swiss franc per capita (Chatagny and Soguel, 2012). Second, we assume that the finance minister is in charge of the department of finance and is responsible for producing tax revenue projections. Thus, an asymmetry of information in favour of the finance minister exists in the budgeting process. This feature does not seem to be particular to Swiss cantons. In the context of European countries, von Hagen (2010, p.489) mentions that:" Among the ministers, only the minister of finance has the resources and administrative capacity to produce the economic and fiscal forecasts published by the government. The minister of finance is also typically responsible for managing the annual budget process. This gives him a considerable informational and strategic advantage over the other cabinet members, which he can use to pursue his political agenda". Finally, we assume that manipulating revenue projections is the less costly way for the finance minister to influence fiscal policy. This is reasonable and realistic since, in order to change the tax law or to reduce expenditure, the finance minister needs to convince a majority of spending ministers, a majority of parliament members and, as is often the case in Swiss cantons due to financial referenda, a majority of voters. The three assumptions that have just been formulated will underlie the following discussion, starting with the effect of the ideology of the finance minister on TRPE.

\subsection{Expected effect of the FM's Ideology on Revenue Projection errors}

Under the assumptions presented above and everything else being equal, one would intuitively expect a right-wing finance minister to produce relatively more conservative projections in order to achieve a relatively

lower level of expenditure. In this study, we intend to go beyond intuition by conducting a different line of argument, which is based on the idea that elections are a way of selecting the most competent politician (Persson and Tabellini, 2000, p.81). This kind of model was developed by Rogoff and Sibert (1988) and Rogoff (1990) to analyse fiscal policy and the political business cycle. Such models assume that voters do not have full information about the competence of politicians, which implies that voters are backward looking because the past performance of incumbents provides information about their competence. Consequently, incumbents also have an incentive to use policies to send signals to the voters about their competence. In the context of tax revenue projections, it does not appear realistic to argue that the finance minister uses TRPE per se to send a signal to the voters. Actually, it does not appear realistic to assume that voters look at 
revenue projection errors in order to assess politicians' performance. Projection errors do not get important media coverage and remain largely disregarded by the public. However, the actual level of expenditure or deficit, partly resulting from the revenue projections, can be observed by voters and used to infer how competent the finance minister is. In this paper, we define the competence of the finance minister as his/her ability to balance the budget by reducing deficits. This definition of competence is based on the fact that, within the cabinet, the finance minister is the only politician responsible for the overall budget. It is therefore natural to think that voters will evaluate the competence of the finance minister according to his/her ability to keep the budget balanced. This idea is backed up by some empirical evidence showing that voters punish incumbents who run deficits. In a study on 74 countries, Brender and Drazen (2008, p.2215) find that :"voters, especially in developed countries and established democracies, do not like deficits". Furthermore, since each spending minister is responsible for only a share of the budget, the finance minister operates in the context of a deficit bias, the so-called common-pool problem applied to the public budget (Weingast et al., 1981; Velasco, 2000; Borge, 2005; Schaltegger and Feld, 2009; van der Ploeg, 2010; Baskaran, 2013). This common-pool problem is likely to be more severe the higher the number of political parties that are represented among the spending ministers. This is what we call the weak government hypothesis (de Haan et al., 1999; Perotti and Kontopoulos, 2002). Coalitions are indeed the rule rather than the exception in Swiss cantonal cabinets. ${ }^{2}$ In such a context, the finance minister has an incentive to underestimate tax revenue irrespective of whether he/she is a left-wing or right-wing finance minister. ${ }^{3}$ Therefore one may wonder in what way ideology plays a role in such a setting. Party affiliation is information about the finance minister which is public. It is a signal about the finance minister's ideology that is sent to the voters and from which they can infer their competence. Here we argue that, everything else being equal, a left-wing finance minister will be seen by the voters as less competent $\boldsymbol{a}$ priori - no matter whether this is true or not - than a right-wing finance minister when it comes to curbing deficits and balancing the budget. This argument is both reasonable and realistic. The prior belief that left-wing incumbents are likely to generate larger deficits than their right-wing counterparts is both widespread among scholars and in the general public. Since the seminal contribution by Hibbs (1977), the hypothesis that left-wing governments generate higher budget deficits has been formulated and tested in numerous empirical studies. In spite of mixed evidence, this hypothesis is still dominant in the literature. One of the most recent cases in point which is closely related to this study is the study by Jochimsen and Thomasius (2014) who formulate the hypothesis that deficits are higher under a left-wing finance minister. In the Swiss context, opinion surveys

\footnotetext{
${ }^{2}$ Cantonal governments are characterized by a rather high degree of political fragmentation. Indeed, in our sample, there are at least two parties in power in more than 75 per cent of the cases. See summary statistics for the variable called "Fragmentation" in Table $(.9)$.

${ }^{3}$ This argument is backed up by the fact that, in all Swiss cantons except Bern tax revenue are underestimated. See Table 1
} 
suggest that right-wing parties are perceived as more credible when it comes to fiscal policy. ${ }^{4}$ This prior belief of voters that left-wing finance ministers are less likely to balance the budget combined with their preference for balanced budgets create an incentive for left-wing finance ministers to signal that they are at least as competent as right-wing finance ministers. Therefore, in order to signal the same level of competence as a right-wing finance minister, a left-wing finance minister needs to produce lower deficits and, therefore, underestimate tax revenue to a larger extent. In line with this last prediction, we formulate our first testing hypothesis :

(H1) left-wing incumbent finance ministers produce more conservative direct tax revenue projections

\subsection{Incentive effects of fiscal rules}

Provided an effect of ideology on tax revenue projection errors is observed, one may also wonder whether the implementation of fiscal rules may alter this relationship. Fiscal rules render the creation of deficits more costly for instance by imposing automatic expenditure cuts and/or tax increases which may be very costly to incumbents from an electoral point of view. Therefore, depending on their degree of stringency, fiscal rules are expected to create incentives for the spending ministers to be more cautious in their spending claims in order to avoid high deficits. Numerous empirical studies provide evidence that fiscal rules are effective in reducing fiscal deficits and/or debt accumulation (see, among others, Bohn and Inman (1996); Feld and Kirchgaessner (2008); Canova and Pappa (2006); Debrun et al. (2008); Blume and Voigt (2013)). Fewer studies look at the effect of fiscal rules on fiscal projections. While Pina and Venes (2011) do not find any effect of balance budget rules on deficit forecasts, Luechinger and Schaltegger (2013) show that fiscal rules increase the probability of accurate deficit projections by reducing the over-pessimistic bias in projections. Without showing it explicitly, this last study on the Swiss cantons suggests that, in the presence of a balanced budget fiscal rule, the necessity to reduce deficits by underestimating tax revenue is expected to be lower, irrespective of the ideology of the finance minister. Even if curbing deficits turns out to be necessary, voters may attribute a reduction in deficits to the implemented fiscal rule rather than to the competence of the finance minister. This makes a further reduction in deficits a less informative signal to the voters about the competence of the finance minister. Therefore, the finance minister has an incentive to engage in other types of signalling activity which, under a fiscal rule, is relatively more informative to the voters. This incentive is stronger for relatively more left-wing finance ministers since they need to compensate for the negative

\footnotetext{
${ }^{4}$ In a 2008 opinion survey, respondents considered the main Swiss right-wing parties, CVP, FDP and SVP as very or rather credible in $38 \%, 37 \%$ and $50 \%$ of the cases while left-wing parties (SP and GPS) are seen as credible in $35 \%$ of the cases. Conversely, the right-wing parties are perceived as absolutely not credible in 15\%, 10\% and 16\% of the cases while the left-wing parties received 21\% (see Longchamp, C., Finanzmonitor 2008 Souverän für eine Nachhaltige Finanzpolitik, Economiesuisse, 2008).
} 
signal sent by their ideology. The stronger reaction of the left-wing finance ministers imply that fiscal rules must reduce the positive effect of ideology on tax revenue projection errors. Consequently, we can state our second testing hypothesis as follows :

(H2) The effect of the ideology of the finance minister on tax revenue projection errors decreases with the stringency of fiscal rules.

In order to test our hypotheses, we rely on a panel dataset of the 26 Swiss cantons over the period 1980-2007 as well as a new dataset of 99 finance ministers at the cantonal level. We present the background of the Swiss cantons and our data in more detail in the next section.

\section{Institutional background and data}

In Switzerland, the cantons form the sub-national level of the government. They possess well established institutions such as a constitution, a government and a parliament and enjoy a high degree of budgetary autonomy. They make up for about 40 percent of total public expenditure and revenue. They also have a high degree of sovereignty to levy, collect and predict taxes. For instance, they can decide on a tax coefficient and on the progressivity of the tax schedule that applies to personal income. They generate 47 percent of the total personal income tax revenue while the additional revenue is collected by the federal state and the municipalities. In aggregate, direct tax revenue (personal and corporate income tax) represent about 46 percent of the cantons' current revenue. Transfers represent 31 percent while excise, fees and other tax revenue represent 23 percent of cantonal current revenue.

\subsection{Revenue Projections in Swiss cantons}

In order to identify the effect of the finance minister's ideology on revenue projections, we focus on direct taxes. Indeed, transfers are paid and therefore predicted by other levels of jurisdiction than the cantons. For instance, the federal administration produces a publicly available projection of the transfers paid to each canton in the frame of the national fiscal equalization. When it comes to fees, excise or other taxes, it may not be the department headed by the finance minister that is responsible for collecting revenue and producing projections. For instance, in the canton of Zürich, the tax on vehicles ("Verkehrsabgabe"), is collected by the Road and Traffic Office ("Strassenverkehrsamt") which depends on the Department for Security ("Sicherheitsdirektion") and not the Department of Finance. These examples show that the prediction of transfers and fees is not in the hands of the finance minister and does not leave him with room to manoeuvre.

Direct tax revenue however is collected and predicted by each canton's own tax offices. In every canton, without exception, the tax office directly depends on the department of finance, which is headed by the incumbent finance minister. The cantonal departments of finance are very independent in producing direct revenue projections. While in some cantons the department of finance is responsible for producing direct tax 
revenue forecasts for the municipalities, it does not have to apply projections or other data that are provided by the federal state. In spite of the fact that the federal state and the cantons share the same tax base for direct taxes, they produce projections only for their own budgets independently of each other. Furthermore, cantonal departments of finance are free to use any data source ranging from individual taxpayer data to macroeconomic forecasts or municipal data in order to produce their projections. They are also free to use any methodology such as micro simulations, time series analysis or more intuitive experts' judgemental estimations. The methodologies are not presented in details in official and publicly available documents and the projection errors are not systematically assessed. Even the technical forecast, as produced by the tax revenue office, is not publicly available. Among the members of the cantonal cabinet, only the finance minister has direct access to this information. Finally, the projection made by the department of finance is not challenged by alternative forecasts. No governmental or independent institution produces their own revenue projection for individual cantons and for detailed revenue items. Overall, the direct tax revenue budgeting process in Swiss cantons provides the finance minister with a high degree of control and a strong informational advantage towards other players in the budgeting process. Note that finance ministers in Swiss cantons are not vested with particular powers like veto or agenda-setting power like in European countries, for instance. ${ }^{5}$ In that sense, the position of finance ministers in Swiss cantons appears to be relatively weak with respect to fiscal policy choices. This makes revenue projection a particularly appealing tool to influence fiscal policy decisions. In order to identify possible manipulations in revenue projections, we computed direct tax revenue projection errors as explained in the next section.

\subsection{Data on direct tax revenue projection errors}

In order to compute direct tax revenue projection errors, we collected projected as well as realized direct tax revenue as published in cantonal public accounts over the period 1980-2007. ${ }^{6}$ In the literature about tax revenue forecasting accuracy, ${ }^{7}$ absolute errors are often used as an indicator in order to avoid positive and negative errors offsetting each other. However, in this paper, we are looking to find precise information about the direction in which projections are potentially manipulated. Thus, we choose the difference between the projected amount of tax revenue and the actual amount. Cantonal population has been chosen as the denominator. This allows us to compare tax revenue projection errors between cantons. Thus, our main indicator measuring tax revenue projection errors may be expressed as follows :

$$
\operatorname{Error}_{i j t}=\frac{\left(R_{i j t}^{p}-R_{i j t}^{a}\right)}{P_{i j t}}
$$

\footnotetext{
${ }^{5}$ For example, see von Hagen (2010) for a presentation on the budgetary institutions in the European context.

${ }^{6}$ Note that, over the period of interest 1980-2007, public accounts do not distinguish between personal and corporate tax revenue for every canton and/or every time span. For this reason, we used what we call "direct taxes", i.e. the addition of both personal and corporate tax. Using this aggregate allows us to use of a complete and homogenous dataset across both cantons and years.

${ }^{7}$ See for example Mocan and Azad, 1995, p.419
} 
,where $R$ denotes Direct Tax Revenue, the subscript $a$ stands for actual, the subscript $p$ stands for projected and $P$ denotes the cantonal population. $i$ identifies finance ministers, $j$ identifies cantons and $t$ identifies years. Table (1) lists summary statistics for the average TRPE over time for each canton. Cantons are ranked according to the average tax revenue budgeting error over the considered period.

Table 1: Tax Revenue Projection Errors per Capita (1980-2007)

\begin{tabular}{lcccccc}
\hline \hline canton & mean & sd & min & max & range & N \\
\hline BE & 36.96827 & 81.64759 & -129.2704 & 201.4522 & 330.7226 & 28 \\
UR & -14.06001 & 128.6291 & -293.7344 & 237.378 & 531.1124 & 28 \\
SH & -15.59604 & 76.27386 & -135.4608 & 168.287 & 303.7477 & 28 \\
JU & -16.72336 & 61.70619 & -147.9202 & 89.91608 & 237.8363 & 28 \\
AR & -23.40973 & 59.14726 & -110.858 & 128.5307 & 239.3887 & 28 \\
ZH & -23.456 & 137.3845 & -433.2509 & 174.6628 & 607.9137 & 28 \\
SO & -26.40169 & 132.1977 & -287.9469 & 300.2846 & 588.2315 & 28 \\
TG & -35.07672 & 83.22178 & -183.1832 & 145.8114 & 328.9946 & 28 \\
NE & -35.27104 & 120.2942 & -267.6661 & 224.1479 & 491.814 & 28 \\
LU & -41.15983 & 91.98276 & -237.707 & 139.6689 & 377.3759 & 28 \\
SG & -43.58655 & 76.21494 & -219.4491 & 152.3872 & 371.8363 & 28 \\
OW & -54.33199 & 83.78898 & -193.8892 & 179.7751 & 373.6643 & 28 \\
AG & -55.51718 & 112.7451 & -246.1751 & 195.932 & 442.1071 & 28 \\
NW & -65.94932 & 120.5269 & -538.529 & 104.1314 & 642.6604 & 28 \\
VS & -74.92986 & 93.28039 & -259.4183 & 189.9564 & 449.3747 & 28 \\
VD & -75.06823 & 193.6663 & -552.7347 & 359.1893 & 911.924 & 28 \\
SZ & -75.87744 & 108.8037 & -309.7535 & 157.1612 & 466.9147 & 28 \\
GR & -85.87241 & 57.24932 & -188.2635 & 45.87022 & 234.1338 & 28 \\
FR & -101.8898 & 90.83454 & -383.7159 & 64.05879 & 447.7747 & 28 \\
GE & -113.9392 & 528.3911 & -1430.055 & 1142.728 & 2572.783 & 28 \\
AI & -122.1199 & 121.228 & -344.7328 & 98.15961 & 442.8924 & 28 \\
GL & -137.1442 & 191.3831 & -437.0659 & 233.31 & 670.3759 & 28 \\
BL & -144.7217 & 199.0107 & -839.1275 & 149.5214 & 988.6489 & 28 \\
TI & -157.4365 & 206.4838 & -571.5998 & 269.7093 & 841.3091 & 28 \\
BS & -193.2389 & 489.8768 & -1237.159 & 556.99 & 1794.149 & 28 \\
ZG & -222.5467 & 213.0142 & -672.3793 & 263.3303 & 935.7096 & 28 \\
Tot & -73.78293 & 193.3494 & -1430.055 & 1142.728 & 2572.783 & 728 \\
\hline & & & & & &
\end{tabular}

It shows that, except for the canton of Bern (BE), all cantons have tax revenue budgeted errors below zero on average. Thus, we clearly observe a tendency to underestimate tax revenue. This pattern is consistent with the idea that the finance minister is operating in the context of a deficit bias, the fiscal common problem, and has an incentive to be conservative in his/her revenue projections independently of his/her ideology. We also observe strong heterogeneity across cantons. While a canton like Bern overestimated direct tax revenue by about 37 Swiss francs per capita on average, cantons like Basel-Stadt or Zug massively underestimated their tax revenue with, respectively, -193 and -222 Swiss francs per capita over the same period. We naturally expect the characteristics of the finance minister - in particular his/her ideology - to explain an important part of the observed inter-cantonal and inter-temporal variability. Indeed, due to their position within the government cabinet, the finance minister is expected to have a particularly high influence on projected tax revenue and, therefore, on TRPE.

\subsection{Finance ministers in the Swiss cantons : a new dataset}

In order to test whether the ideology of the finance minister indeed has an impact on revenue projections, we collected personal data on 99 finance ministers from 1980-2007. Table (2) presents the indicator used to 
measure ideology.

Table 2: Main Political Parties in Cantonal Governments and Their Political Leaning

\begin{tabular}{rrrrrrrrr}
\hline \hline Party & SP & GPS & CSP & CVP & FDP & PLS & SVP & Lega \\
\hline Ideology & 2.6 & 3.2 & 5 & 5.4 & 6.8 & 7.6 & 7.7 & 8.2 \\
\hline
\end{tabular}

First, the different parties encountered within cantonal cabinets over the period 1980-2007 are presented in the first row of Table (2). ${ }^{8}$ Then, a measure of the corresponding ideological position of the parties on a left-right scale is reported in the second row of Table (2). This scale ranges from zero to 10, zero being the far left and 10 the far right. This type of left-right scale is frequently used by political scientists (Ladner, 2006) to quantify the leaning of political parties and is constructed as follows. Presidents of cantonal branches of Swiss political parties are asked to assess their own party on the right-left scale. The assessments made by the presidents of cantonal branches are then averaged which gives the value for the party on the scale (Ladner, 2006). ${ }^{9}$ In order to construct a measure for the ideology of the finance minister, we attribute to them the value that corresponds to the position of their political party on the scale. In our empirical analysis, we also control for the average ideology of the spending ministers. Summary statistics are reported in Table (3). We can see (row called "Finmin") that the distribution of the ideology of finance ministers is

Table 3: Ideology of Finance and Spending Ministers (1980-2007)

\begin{tabular}{lccccccc}
\hline \hline & mean & 25th perc. & median & 75th perc. & sd & $\min$ & $\max$ \\
\hline Finmin & 5.97 & 5.4 & 5.4 & 6.8 & 1.35 & 2.6 & 7.7 \\
Spendmin & 5.46 & 5.05 & 5.41 & 5.75 & 0.555 & 3.8 & 7.1 \\
\hline Diff & -0.51 & -1.75 & -0.7 & 0.23 & 1.52 & -3.63 & 3.78 \\
\hline
\end{tabular}

skewed to the right. One may argue that the average ideology of the finance minister and of the spending ministers are very close and that the ideology of the finance minister is just a proxy of the ideology of the whole cabinet. Note first that actually the difference between the average ideology of finance and spending ministers is statistically significant. ${ }^{10}$ Furthermore, in our empirical analysis we also include a measure of the ideology of the spending ministers as well as a measure of the ideology of the cabinet as a whole and show that the finance minister's ideology is still significant.

In order to obtain a precise identification of the effect of the finance minister's ideology on tax revenue projections, we also collected additional data on the characteristics of the finance minister. They are reported in Table 4. The variables "Age", "Gender" and "Years in office" are obvious. The dummy variable "Power"

\footnotetext{
${ }^{8}$ From the left to the right, the main political parties represented in cantonal governments are : the Social Democratic Party (SP), the Green Party (GPS), the Christian Social Party (CSP), the Christian Democratic People's Party (CVP), The Liberals (FDP), the Liberal Party (PLS), the Swiss People's Party (SVP) and the Ticino League (Lega).

${ }^{9}$ Note that this indicator is not computed every year, which prevents us from controlling for shifts of political parties over time on the scale and forces us to assume that the ideology of the Swiss political parties is stable over time.

${ }^{10}$ Under the null that both means are equal, the Hotelling statistic is 103.15 and the p-value is 0.000 .
} 
Table 4: Finance Minister Characteristics : Summary Statistics

\begin{tabular}{lccccc}
\hline \hline \multicolumn{1}{c}{ Variable } & Mean & Std. Dev. & Min. & Max. & $\mathbf{N}$ \\
\hline Age & 52.237 & 6.558 & 33 & 69 & 712 \\
Gender & 0.092 & 0.289 & 0 & 1 & 728 \\
Years in office & 5.402 & 3.654 & 1 & 18 & 728 \\
Power & 0.88 & 0.325 & 0 & 1 & 728 \\
President & 0.166 & 0.373 & 0 & 1 & 728 \\
Federal Council & 0.033 & 0.179 & 0 & 1 & 728 \\
\hline
\end{tabular}

takes value 1 when the finance minister belongs to the majority. For instance, a right-wing finance minister belongs to the majority if half of the seats in the cantonal cabinet plus one are held by right-wing politicians. The variable "President" takes value 1 in the years during which the finance minister is also president of the cantonal government. Finally, we intend to capture career concerns of finance ministers by including a dummy variable taking value 1 whenever a finance minister is elected to the Federal Council, which is the highest possible political position within an executive governmental entity in Switzerland.

\subsubsection{Finance ministers' ideology and TRPE}

Of all the characteristics presented above, the ideology of the finance minister is expected to be a particularly important driver of tax revenue projection errors. To motivate this claim we report in Table 5 summary statistics for the tax revenue projection errors within each type of ideology of the finance ministers.

Table 5: Direct Tax Revenue Projection Error per Capita by Ideology

\begin{tabular}{lrrrrrr}
\hline \hline Ideology & mean & sd & min & max & range & $\mathbf{N}$ \\
\hline SP & -177.4019 & 287.206 & -1237.159 & 224.1479 & 1461.307 & 60 \\
GP & -1146.358 & 401.2085 & -1430.055 & -862.6603 & 567.3945 & 2 \\
Misc & -101.9834 & 185.0647 & -344.7328 & 167.0657 & 511.7984 & 11 \\
CVP & -66.61592 & 112.7158 & -672.3793 & 300.2846 & 972.6639 & 275 \\
FDP & -84.20896 & 181.4824 & -839.1275 & 436.7046 & 1275.832 & 254 \\
LP & 50.68671 & 387.493 & -1029.024 & 1142.728 & 2171.753 & 32 \\
SVP & -16.68983 & 128.7526 & -437.0659 & 299.5135 & 736.5794 & 94 \\
Total & -73.78293 & 193.3494 & -1430.055 & 1142.728 & 2572.783 & 728 \\
\hline
\end{tabular}

The average projection error exhibits very important differences between types of ideologies of the finance ministers with a tendency of the left-wing finance ministers (SP and GP) to produce a lower average error than the center right finance ministers (CVP and FDP) and than the right-wing finance ministers SVP. These summary statistics not only support the idea that the ideology of the finance minister drives part of the differences observed in tax revenue projection errors but also suggest that left-wing finance ministers tend to produce more conservative forecasts.

To support our argument further we provide in figures 1 to 3 , examples of individual cantons within which the average tax revenue projection error sharply dropped whenever the ideology of the incumbent 


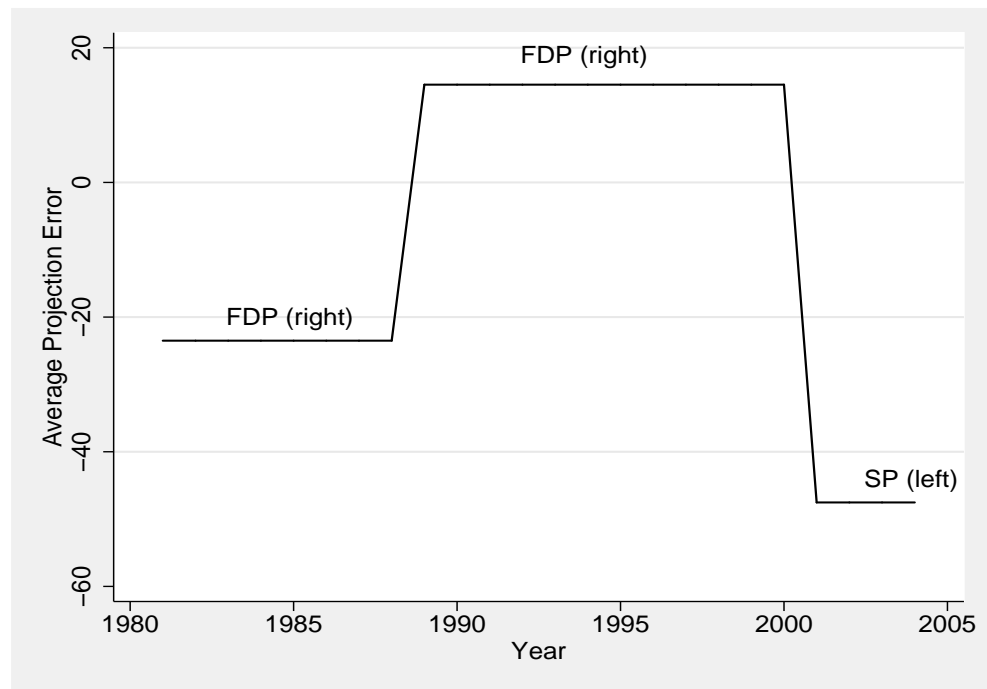

Figure 1: Shift in the Average Revenue Projection Error : Schaffhausen

shifted from right to left. In the figures 1 to 3 the tax revenue projection errors are averaged over the years during which a particular finance minister exercised power. In these examples, we can observe a clear and sharp negative deviation of the average tax revenue projection error whenever the ideology of the finance minister shifts from right-wing to left-wing. What figures also show, however, is that the average error also exhibits some shifts when the ideology of the finance minister does not change. This is especially obvious in figure 1. Clearly, revenue projection errors may be driven by many other factors that must be controlled for in order to obtain a clean estimation of the effect of the ideology of the finance minister and draw some clear-cut conclusions. In particular, fiscal rules are expected to shape TRPE through the incentive effect they have on the behaviour of the finance minister. In the next subsection we explain how balanced budget fiscal rules in the Swiss cantons are empirically addressed.

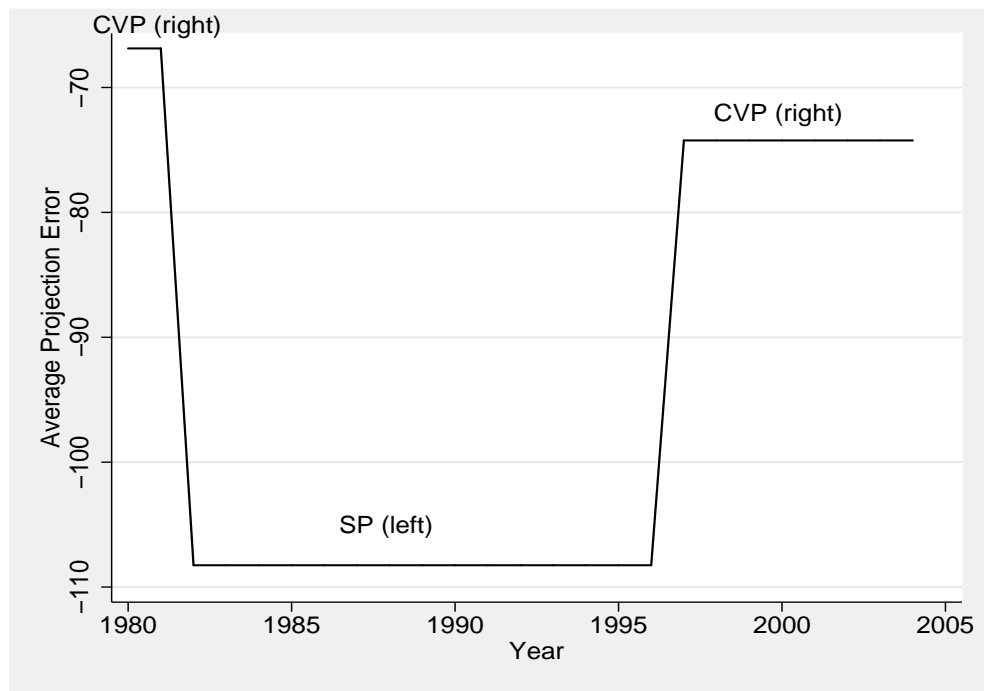

Figure 2: Shift in the Average Revenue Projection Error : Fribourg 


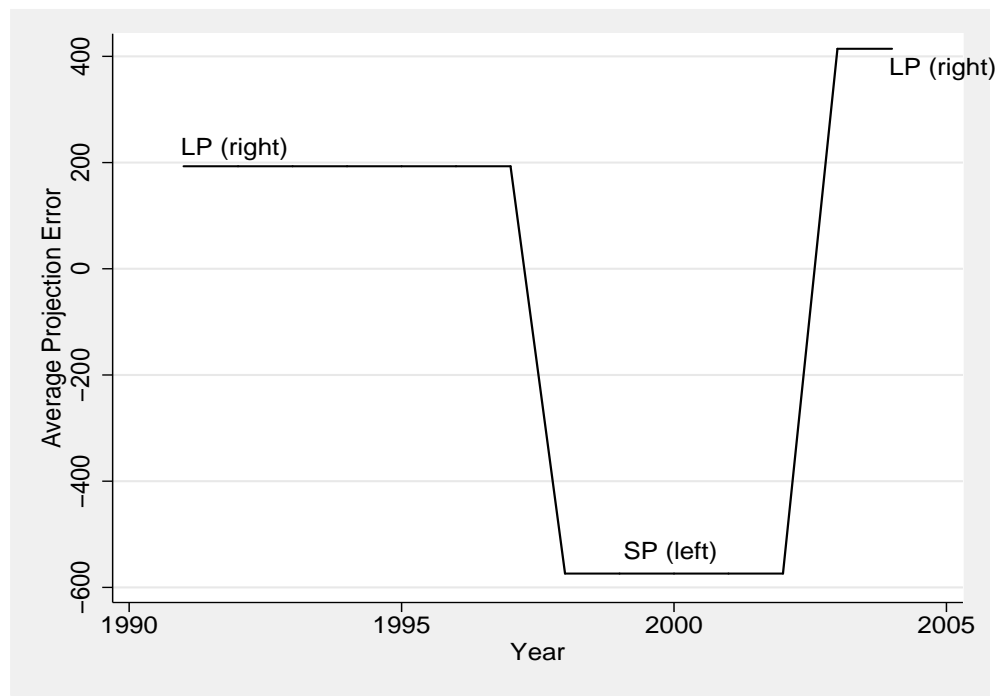

Figure 3: Shift in the Average Revenue Projection Error : Geneva

\subsection{Fiscal rules}

Should an effect of the ideology of the finance minister on TRPE be observed, we expect fiscal rules to reduce it. The context of Swiss cantons is particularly appropriate to test this hypothesis since, between 1980 and 2007, several, but not all, Swiss cantons experienced an introduction of fiscal rules which was staggered over time. Across cantons, fiscal rules also exhibit a relatively high heterogeneity in their degree of stringency. This makes Swiss cantons a particularly appropriate setting for identifying the incentive effects of fiscal rules on cantonal finance ministers.

\subsubsection{Measure of the stringency of fiscal rules}

Table 6: Fiscal Rules Index : Summary Statistics

\begin{tabular}{rrrrrr}
\hline \hline & $\mathrm{N}$ & Mean & S.d. & Min. & Max \\
\hline Fiscal rule index & 728 & 0.452 & 0.943 & 0 & 3 \\
\hline
\end{tabular}

In order to measure the stringency of fiscal rules, we rely on the index suggested by Feld and Kirchgaessner (2008). ${ }^{11}$ The approach developed by Feld and Kirchgaessner (2008) makes use of three criteria to assess the stringency of fiscal rules. ${ }^{12}$ The first criterion assesses whether or not budget planning is strongly connected to actual budget execution. The second criterion captures the existence or absence of strong numerical constraints. The third criterion captures the existence of effective sanctions (in the form of automatic tax adjustments for instance) whenever the numerical constraint is not respected . Using these three criteria, an index of the stringency of fiscal rules from zero (none of the criteria are fulfilled) to three (all of the three

\footnotetext{
${ }^{11}$ For detailed description of this index, see Feld et al. (2011). A detailed description of the legal and constitutional requirements of Swiss cantonal fiscal rules is also provided by Luechinger and Schaltegger (2013).

${ }^{12}$ The following description is based on Feld et al. (2011)
} 
criteria are fulfilled) is constructed for each canton. Table 6 shows the summary statistics for the fiscal rules index. The staggered introduction of fiscal rules in Swiss cantons over the period is illustrated in Appendix 6.

\subsubsection{Fiscal rules, finance ministers' ideology and TRPE}

The observed differences in the use and stringency of fiscal rules across cantons and over time makes Switzerland a particularly appealing laboratory to assess how the incentives created by a fiscal rule does alter the finance minister's behaviour within the tax revenue budgeting process. In particular, as expressed in our second hypothesis, we expect more stringent fiscal rules to reduce the effect of the ideology of the finance minister on revenue projection errors. In order to provide some preliminary evidence supporting this hypothesis, we present in Table 7 the same summary statistics as in Table 5 but we split the sample between the finance ministers operating in the absence of a fiscal rule and those operating in the presence of a fiscal rule.

Table 7: TRPE per Cap. by Ideology with vs without Fiscal Rule

\begin{tabular}{lrrr|rrr}
\hline \hline & \multicolumn{3}{c|}{ no Fiscal Rule } & \multicolumn{3}{c}{ Fiscal Rule } \\
Ideology & mean & sd & N & mean & sd & N \\
\hline SP & -204.3408 & 331.3609 & 43 & -109.2624 & 95.20077 & 17 \\
GP & -1146.358 & 401.2085 & 2 & - & - & - \\
Misc & -101.9834 & 185.0647 & 11 & - & - & - \\
CVP & -70.76875 & 110.5331 & 191 & -57.17319 & 117.6584 & 84 \\
FDP & -86.25381 & 185.1515 & 225 & -68.34375 & 151.8417 & 29 \\
LP & 50.68671 & 387.493 & 32 & - & - & - \\
SVP & -13.78528 & 136.7302 & 68 & -24.28635 & 107.1512 & 26 \\
Total & -77.69327 & 208.5463 & 572 & -59.44502 & 121.9117 & 156 \\
\hline
\end{tabular}

In the absence of a fiscal rule, we can see that the variation of the average tax revenue projection error across ideologies is substantially the same as in Table 5. left-wing finance ministers (SP and GP) produce substantially more negative TRPE than center right finance ministers (CVP, FDP) who, in turn, produce more conservative projections than right-wing finance ministers (LP, SVP). When a fiscal rule does exist, the average tax revenue projection error for left-wing finance ministers (SP) is almost divided by two compared to when no fiscal rule does exist. The average error for center right finance ministers (CVP, FDP) is also less negative. In the case of right-wing finance ministers (SVP), the average projection error turns out to be more negative than in the absence of a fiscal rule. These differences suggest that, under a fiscal rule, the average tax revenue projection error tends to converge across types of ideology which clearly supports the idea that fiscal rules reduce the effect of ideology on tax revenue projection errors, thereby supporting our second hypothesis.

Before presenting our empirical analysis in detail, note that we additionally control for variables at the 
level of cantons and which are traditionally encountered in the literature. ${ }^{13}$ The so-called political budget cycle is captured by a dummy variable equal to 1 for the years when elections are held, and 0 otherwise. ${ }^{14}$ Following Goeminne et al. (2008), we also include a variable controlling for the degree of fragmentation within the government cabinet, measured by the number of parties in the government. We control for political concordance which is measured by the percentage of the seats in the legislature that are occupied by members of parties represented in the executive. We also control for the number of departments which is equivalent to the number of members in the cabinet since, in Swiss cantons, each member of a cantonal government is in charge of a department. The ideology of the executive as a whole is controlled for by the variable "Right" which is measured by the proportion of right-wing members in cantonal executives. "Postnumerando" is a dummy variable taking value 1 when a canton uses the postnumerando taxation system and zero when a praenumerando system is in use. ${ }^{15}$ "Grant" measures the degree of tax autonomy using federal transfers as a share of actual direct tax revenue. Deficit(-1) is the lagged cantonal fiscal balance. Finally, we control for economic conditions with the growth rate of cantonal income (variable "Growth") and the annual change in the cantonal unemployment rate ("Unemployment(D)").

\section{Empirical Analysis}

\subsection{Econometric model}

In this section, we present the methodology used to perform the analysis. The estimated model is formalized by equation 2 below.

$$
\text { Error }_{i j t}=\beta \text { Ideology }_{i j t}+\lambda \text { Rule }_{j t}+\mu\left(\text { Ideology }_{i j t} * \text { Rule }_{j t}\right)+\delta X_{i j t}+\gamma W_{j t}+\alpha+\theta_{j}+\tau_{t}+\epsilon_{i j t}
$$

, where $i=1, \ldots, 99$ identifies finance ministers, $j=1, \ldots, 26$ identifies cantons and $t=1980, \ldots, 2007$ identifies years. Error is our measure of tax revenue projection error. Ideology $y_{i j t}$ is the ideology of the finance minister measured by his party affiliation as explained above, and $\beta$ the associated coefficient measuring the effect on revenue forecast errors. Rule $e_{j t}$ is the index measuring the stringency of fiscal rules. (Ideology $*$ Rule) is an interaction term taking into account the effect of a fiscal rule on the effect of the finance minister's ideology on TRPE. $X_{i j t}$ is a matrix of controls constituted by the personal characteristics of the finance minister as presented in Table 4 , and $\delta$ is the associate vector of parameters. $W_{j t}$ is a matrix of controls at the cantonal level reflecting the economic, political and institutional environment in which the finance minister is exercising power as presented in Table .9 of the Appendix, and $\gamma$ is the associated vector of parameters.

\footnotetext{
${ }^{13}$ The summary statistics are reported in Table .9 of Appendix 6

${ }^{14}$ In the empirical model we include also a lagged and forwarded election dummy to account for ante- and post-elections effects.

${ }^{15}$ Luechinger and Schaltegger (2013) also control for the taxation system.
} 
Note that $W_{j t}$ includes the ideology of the spending ministers as well as three dummy variables for the pre-, post- and electoral year. $\alpha$ is an intercept. $\theta_{j}$ and $\tau_{t}$ are canton and time fixed effects respectively and $\epsilon_{i j t}$ is the error term.

in order to have a clearer picture of how fiscal rules influence the effect of the finance minister's ideology on tax revenue projection errors, it will be of interest to compute the marginal effect of ideology. We can derive it from equation (2):

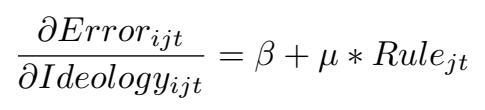

According to our hypotheses, $\beta$ and $\mu$ are expected to be significantly positive and negative respectively. A positive $\beta$ means that a more right-wing finance minister produces relatively less conservative forecasts than a left-wing finance minister. A negative $\mu$ means that the stringency of fiscal rules reduces the average marginal effect of ideology on tax revenue projection errors.

\subsection{Estimation}

The data and, therefore, standard errors are potentially identified over three dimensions : finance minister, canton and year. Standard errors may thus be correlated within the clusters existing in these three dimensions, thereby possibly leading to inference problems. Furthermore, while clusters related to finance ministers and cantons are nested, this is not the case for years and finance ministers or years and cantons. Therefore, in order to estimate equation 2, we follow the methodology suggested by Cameron et al. (2011) for multi-way non-nested clustering. The parameters of interests will be estimated through OLS with cluster-robust standard errors with clustering occurring at the finance minister level and at the year level. Alternative estimators will be used to check for the robustness of the results. System GMM will be used to estimate a dynamic version of the model and a GLS estimator with panel corrected standard errors will also be used in order to better account for the panel specific autoregressive structure of the error term. Results turn out to be robust.

\subsection{Identification}

As usual in any study on the impact of political variables and/or fiscal institutions on fiscal variables one can question whether the estimation is not plagued with endogeneity problems, in particular reverse causality and omitted variable bias. One could argue that all three variables of interest, namely revenue projection errors, finance minister's ideology and fiscal rules are determined by general fiscal conditions and/or citizens preferences. Similarly one could think that tax revenue projection errors are being observed by citizens who modify their voting behaviour and choose the finance minister accordingly. This would mean that TRPE explain part of the finance minister's ideology. In this paper, we argue that our empirical findings can be interpreted in a causal way for several reasons. 
First, we argue that focusing on the sub-aggregate of direct tax revenue allows for a cleaner identification of the effect of the finance minister's characteristics on fiscal outcomes than in similar studies. Indeed, by considering a larger fiscal aggregate, for instance total revenue, one would include items such as transfers from other levels of jurisdiction or fees for the collection and prediction of which the finance minister is not directly responsible. In such a case, some of the identified effects could be falsely attributed to the finance minister when they in fact might have been due to another agent involved in the budgeting process. In this study, focusing on those revenues that are directly under the responsibility of the finance minister makes us confident that the identified effect is attributable to the finance minister.

Second, the context of Swiss cantons offers a very unique environment in which balanced budget fiscal rules have been implemented both with heterogeneous degrees of stringency across cantons and in a staggered way over time, as illustrated in Appendix 6. This feature rules out the eventuality that an exogenous shock affecting all cantons contemporaneously would have simultaneously driven the introduction of fiscal rules as well as variations in the ideology of the finance minister and tax revenue projection errors. In spite of the staggered introduction over time and the heterogeneous design of fiscal rules across cantons, one cannot rule out that the introduction of fiscal rule is related to the past fiscal performance specific to each canton. To account for this, the lagged deficit for each canton has been introduced as a control variable. This allows us to cleanly identify the incentive effect of fiscal rules on the ideological behaviour of the finance minister.

Third, unlike similar studies that consider only the realization of fiscal aggregates such as deficit (Jochimsen and Thomasius, 2014) or debt (Moessinger, 2014), we are looking at the difference between realized and projected revenue. This strategy allows us to naturally control for all those unobserved explanatory variables affecting both realized and predicted revenue in a symmetric way, thereby further reducing potential omitted variable bias. Furthermore, an important limitation of studies considering realized fiscal aggregates as an outcome variable is that these outcomes may be observed by voters who could then choose the finance minister accordingly, thereby causing reverse causality. We argue that using the difference between realized and projected revenues eliminates this reverse causality problem. Indeed, in the Swiss cantons, tax revenue projection errors are not subject to a systematic assessment that would be made publicly available. In most cantons, tax revenue projection errors are not even reported in public accounts. And even when they are, they are not taken into consideration by the media when they report on the state of the cantonal public finances. Therefore, we argue that voters are not informed about tax revenue projection errors - unlike actual revenue or expenditure - and therefore do not use this piece of information at the time when they have to vote for the members of the cantonal cabinet. This fixes potential reverse causality from the tax revenue projection errors on the ideology of the finance minister or on fiscal rules.

And last but not least, another reason supporting the causal interpretation of our empirical results is the fact that the context of Swiss cantons offers a quasi-experimental setting when it comes to the allocation 
of departments to elected politicians. Swiss cantons exhibit majoritarian electoral systems in which the members of the cantonal cabinet are elected individually. ${ }^{16}$ However, the individual politicians do not run for a particular department that would be identified ex ante. After the elections, members of the cantonal cabinet allocate the departments. Neither is this allocation monitored by explicit and binding rules nor is the protocol of the sessions during which the elected politicians bargain over this allocation made public. In fact, departments may be allocated according to very different types of implicit rules or criteria such as seniority in office, electoral score, professional background, personal interests, experience, etc. Even reelected finance ministers are not guaranteed to remain finance minister after their re-election. Therefore, from the point of view of the voters, the allocation of a politician with a certain ideology to the department of finance is quasi-random. Voters cannot anticipate which politician is going to become finance minister. This argument is supported by our sample data as the average number of years a finance minister stays in office is 5.4 (see Table 4). ${ }^{17}$ Provided that the electoral period lasts four or five years, this statistic means that the politician in charge of the department of finance changes rather frequently which makes it difficult for the voters to predict the outcome of the allocation process. This frequent change of finance minister has also been illustrated with some selective cases in figures 1 to 3 . For all the reasons just mentioned, we are confident in the causal interpretation of the empirical results found, which we present in the next section.

\section{Results}

\subsection{Main results}

The main regression results are reported in Table 8 . The dependent variable is the direct tax revenue error per capita as defined by expression 1. The first column reports results for the full specification of our model as formalized in equation (2). The other columns check for the robustness of the results to the exclusion of certain groups of controls. The coefficient for "Ideology" is positive and strongly significant which indicates that the more to the right the political leaning of the finance minister is, the less conservative the revenue projections are. Furthermore, this relationship seems to be very robust to changes in the specification of the model. This result tends to support our theoretical argument that a left-wing finance minister needs to curb deficits relatively more and thereby produce more conservative forecasts than a right-wing finance minister in order to compensate for the negative signal sent by his/her ideology to the voters and to be considered at least as competent by the voters, everything else being equal. In the literature, Tavares (2004) finds a similar - although not completely identical - mechanism when it comes to fiscal adjustments. Indeed, he shows that left-wing parties gain credibility whenever they undertake adjustments that go against the preferences of their

\footnotetext{
${ }^{16}$ The election system is majoritarian in all cantons except Zug and Ticino. Note that, in spite of the fact that the electoral system is majoritarian in almost every canton, cantonal governments are characterized by a rather high degree of political fragmentation. Indeed, in our sample, there are at least two parties in power in more than 75 per cent of the cases.

${ }^{17}$ The median number of years in office is five years.
} 
Table 8: Main Regression Results

\begin{tabular}{|c|c|c|c|c|c|}
\hline & $(1)$ & $(2)$ & $(3)$ & $(4)$ & $(5)$ \\
\hline Ideology & $\begin{array}{c}72.24^{* * *} \\
(7.297)\end{array}$ & $\begin{array}{c}69.57^{* * *} \\
(6.989)\end{array}$ & $\begin{array}{c}38.46^{* * *} \\
(8.031)\end{array}$ & $\begin{array}{c}63.38^{* * *} \\
(8.000)\end{array}$ & $\begin{array}{c}69.09^{* * *} \\
(6.257)\end{array}$ \\
\hline Rule & $\begin{array}{c}61.22 \\
(44.45)\end{array}$ & $\begin{array}{c}54.77 \\
(40.51)\end{array}$ & $\begin{array}{l}25.23^{*} \\
(14.35)\end{array}$ & $\begin{array}{c}67.64^{* *} \\
(31.89)\end{array}$ & $\begin{array}{l}79.08^{*} \\
(41.97)\end{array}$ \\
\hline Ideology x Rule & $\begin{array}{c}-10.84^{*} \\
(6.480)\end{array}$ & $\begin{array}{l}-9.601 \\
(6.228)\end{array}$ & $\begin{array}{l}-0.742 \\
(3.426)\end{array}$ & $\begin{array}{c}-11.42^{* * *} \\
(4.013)\end{array}$ & $\begin{array}{c}-13.46^{* *} \\
(5.513)\end{array}$ \\
\hline Pre-election year & $\begin{array}{c}-31.02^{* *} \\
(13.18)\end{array}$ & $\begin{array}{c}-29.41^{* * *} \\
(9.904)\end{array}$ & $\begin{array}{c}-34.56^{* *} \\
(14.25)\end{array}$ & & $\begin{array}{c}-30.40^{* * *} \\
(11.78)\end{array}$ \\
\hline Election year & $\begin{array}{l}-4.843 \\
(13.16)\end{array}$ & $\begin{array}{c}-6.142 \\
(13.83)\end{array}$ & $\begin{array}{l}-5.849 \\
(15.58)\end{array}$ & & $\begin{array}{l}-3.602 \\
(13.05)\end{array}$ \\
\hline Post-election year & $\begin{array}{c}-17.66^{*} \\
(9.102)\end{array}$ & $\begin{array}{c}-15.26^{*} \\
(8.361)\end{array}$ & $\begin{array}{c}-21.73^{* *} \\
(10.82)\end{array}$ & & $\begin{array}{l}-15.76^{*} \\
(8.840)\end{array}$ \\
\hline Minister controls & Yes & Yes & Yes & Yes & No \\
\hline Canton controls & Yes & Yes & Yes & No & Yes \\
\hline Canton FE & Yes & Yes & No & Yes & Yes \\
\hline Time FE & Yes & No & Yes & Yes & Yes \\
\hline R-squared & 0.3314 & 0.2521 & 0.2534 & 0.3162 & 0.3179 \\
\hline F-test (p-value) & 0.0000 & 0.0000 & 0.0000 & 0.0000 & 0.0000 \\
\hline Observations & 653 & 653 & 653 & 709 & 669 \\
\hline
\end{tabular}

constituencies, i.e. whenever they reduce expenditures. By finding an effect of the ideology of the finance minister on TRPE and by proposing an innovative identification strategy, our empirical analysis contributes to the literature on revenue projections. (Feenberg et al., 1989; Bretschneider et al., 1989; Bretschneider and Gorr, 1992; Mocan and Azad, 1995; Jones et al., 1997; Cassidy et al., 1989; Deschamps, 2004; Voorhees, 2004; Campbell and Ghysels, 1997; Couture and Imbeau, 2009; Ohlsson and Vredin, 1996; Paleologou, 2005; Goeminne et al., 2008; Bischoff and Gohout, 2010; Beetsma et al., 2013). While many of these studies look at the ideology of the government as a whole, none have looked at the role of the finance minister. Our results also extend the literature on the effect of the personal characteristics of individual politicians on fiscal outcomes. ${ }^{18}$ More precisely, this paper is the first to identify a causal relationship between the ideology of the finance minister and a fiscal outcome variable. Jochimsen and Thomasius (2014) look at how personal characteristics of the finance ministers in German states between 1960 and 2009 influence budget deficits. They use a dummy variable taking value one when the finance minister is left-wing. They do not find any significant effect. Similarly, Moessinger (2014) does not find any significant impact of the left-wing ideology of the finance minister on the increase in debt-to-GDP in European countries.

The parameter associated with the interaction term between fiscal rules and the finance minister's ideology

\footnotetext{
${ }^{18}$ For a review of the literature, see Hayo and Neumeier (2014).
} 
turns out to be significant and negative. This result is not robust only in the cases where canton or time fixed effects are dropped (column (2) and (3)). However, joint tests of significance show that canton and time fixed effects should be included in the model. ${ }^{19}$ This negative sign means that the more stringent fiscal rules are, the smaller the positive effect of the ideology of the finance minister on tax revenue projection errors is. Note that the direct effect of fiscal rules (row "Rule" in Table 8) on projection errors is not significant. This suggests that, if fiscal rules have an effect on TRPE, this effect is channelled through the behaviour of the finance minister.

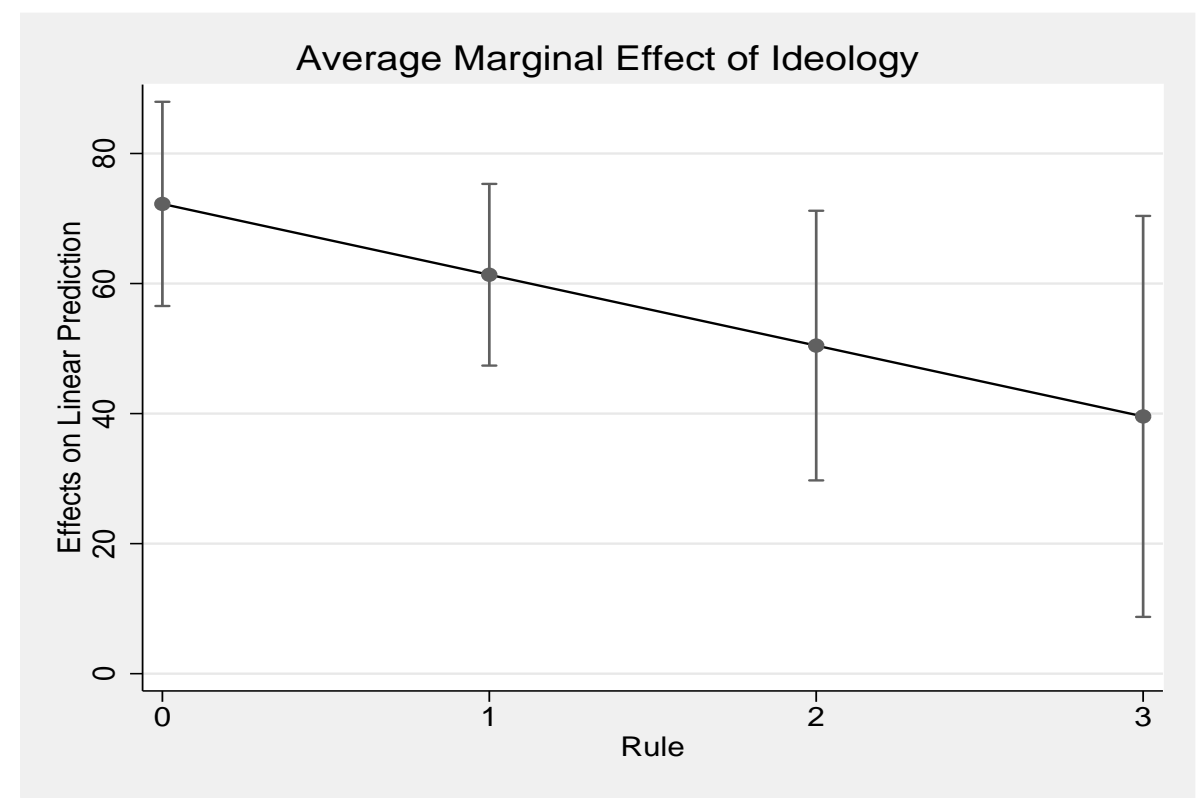

Figure 4: Average Marginal Effect of Ideology on Revenue Projections

To illustrate more precisely how the stringency of fiscal rules alters the effect of ideology on tax revenue projection errors, we have computed and plotted the marginal effect of the finance minister's ideology as formulated in expression (3). As shown in Figure (4), the marginal effect of Ideology unambiguously decreases when fiscal rules become more stringent. The marginal effect turns out to be significant at any value of the fiscal rule indicator. ${ }^{20}$ This result is in line with our theoretical argument, thereby suggesting that fiscal rules tend to render the signal sent by a reduction in deficits less informative to the voters and create incentives for the finance minister to engage in other types of signalling activities. This reduces the necessity for the finance minister to underestimate tax revenue. This incentive is stronger for left-wing finance ministers since they have to compensate for the negative signal sent by their ideology to the voters. Our results show, for the first time, that fiscal rules tend to reduce political manipulations of revenue projections. This is in line with Luechinger and Schaltegger (2013) who argue, without showing it explicitly, that fiscal rules, by curbing

\footnotetext{
${ }^{19}$ The value of the Chi2 of the test for joint significance(with 25 degrees of freedom) of the canton and time fixed effects is 30813.31 and 3945.12 respectively.

${ }^{20}$ The marginal effect and its significance at every level of stringency of fiscal rules is reported in Table .10 of the Appendix.
} 
the spending ministers financial appetite, reduce the necessity for the finance minister to be conservative in revenue projections. Therefore, by identifying a channel through which balanced budget rules affect TRPE, this paper extends the literature on the effect of budgetary institutions on fiscal outcomes.

\subsection{Robustness checks}

In order to assess the robustness of our results and also to better understand what drives them, we performed different robustness checks. Table 8 already provides information about the robustness of our results to the exclusion of certain controls and fixed effects which we already discussed. A natural battery of robustness checks to perform pertains to the exclusion of individual cantons and finance ministers. Qualitatively our results are very robust since the sign of the parameter associated with the ideology of the finance minister and the sign of the parameter of the interaction term never change. The parameter for ideology is always very significant and is insensitive to the exclusion of individual finance ministers or cantons. Although the parameter associated with the interaction term is always negative, its significance and magnitude turn out to be sensitive to the exclusion of individual cantons or finance ministers. Interestingly, the significance drops only when left-wing finance ministers - i.e. from the socialist or the green party - or cantons in which left-wing finance ministers have exercised power are excluded from the sample. This shows that the interaction effect is particularly driven by left-wing finance ministers and supports our theoretical argument. $^{21}$

Furthermore, we also used alternative estimators to estimate our model. More precisely we estimated a dynamic version of the model that includes the lagged tax revenue projection error and the twice lagged tax revenue projection error. We estimated this dynamic version of the model alternatively with the system GMM estimator (Arellano and Bover, 1995; Blundell and Bond, 1998) and with the GLS estimator with panel corrected standard errors suggested by Beck and Katz (1995). Results are reported in Table .11 in the appendix and show that our results are robust to this alternative specification and estimation strategy.

Finally, one may argue that the direction and the size of the effect of the ideology of the finance minister does not depend on the finance minister's absolute position on the left-right scale but rather on his/her position relative to the spending ministers. To check for the robustness of our results to this hypothesis we included the difference between the ideology of the finance minister and the average ideology of the spending ministers in the model and estimated it. The results are reported in Table .12 and show that the ideological gap between the finance minister and the spending ministers is very significant. Nonetheless our results remain unaltered by the inclusion of the ideological gap between the finance minister and the spending ministers.

\footnotetext{
${ }^{21}$ Due to the high number of regressions (125) these robustness checks represent, the results are not reported in the current paper. However, they are available upon request.
} 


\section{Conclusion}

This paper analyses the effect of the ideology of the finance minister on tax revenue projection errors. It also explores how fiscal rules alter this effect. We use a panel dataset of 26 Swiss cantons over the period 1980-2007 as well as a new dataset of 99 finance ministers at the cantonal level and exploit the quasi-random allocation of the departments to politicians elected in the cantonal cabinet. We identify an effect of the ideology of the finance minister on tax revenue projection errors and find the rather counter-intuitive result that a more left-wing finance minister produces more conservative forecasts. We also find a negative effect of the interaction between the ideology of the finance minister and a fiscal rules index, showing that more stringent fiscal rules tend to reduce the positive effect of the ideology. These empirical findings tend to support the idea that left-wing finance ministers need to compensate for the negative signal sent by their publicly-known ideology when it comes to their ability to balance the budget. Therefore, everything else being equal, left-wing finance ministers need to curb deficits more and therefore be more conservative in their projections than right-wing finance ministers in order to signal the same level of competence to the voters. Our findings also support the idea that fiscal rules render the reduction of deficits by finance ministers less informative about their competence and create incentives to engage in other types of signalling actions. This incentive effect is stronger for left-wing finance ministers since they need to compensate for the negative signal sent by their ideology.

More generally, our evidence suggests that asymmetric information about expected tax revenue creates opportunities for the finance minister to manipulate revenue projections and influence fiscal policy. It also provides some evidence that fiscal rules seem to reduce these manipulations. Another way to reduce manipulation one could advocate is to reduce the degree of asymmetric information. Having a higher number of competing and independently produced tax revenue forecasts could contribute to reducing the asymmetry of information between the finance minister and the spending ministers or the members of the parliament thereby reducing the possibilities of manipulation. 


\section{References}

Arellano, M. and O. Bover (1995). Another look at the instrumental variable estimation of errorcomponents models. Journal of Econometrics 68, 29-51.

Baskaran, T. (2013). Coalition governments, cabinet size, and the common pool problem: Evidence from the german states. European Journal of Political Economy 32(0), 356 - 376.

Beck, N. and J. N. Katz (1995). What to do (and not to do) with time series-cross section data in comparative politics. American Political Science Review 89, 634-647.

Beetsma, R., M. Giuliodori, M. Walschot, and P. Wierts (2013). Fifty years of fiscal planning and implementation in the netherlands. European Journal of Political Economy 31(0), 119 - 138.

Bischoff, I. and W. Gohout (2010). The political economy of tax projections. International Tax and Public Finance 17(2), 133-150.

Blume, L. and S. Voigt (2013). The economic effects of constitutional budget institutions. European Journal of Political Economy 29(0), 236 - 251.

Blundell, R. and S. Bond (1998). Initial conditions and moment restrictions in dynamic panel data models. Journal of Econometrics 87, 115-143.

Bohn, H. and R. P. Inman (1996). Balanced-budget rules and public deficits: evidence from the u.s. states. Carnegie-Rochester Conference Series on Public Policy 45(1), 13-76.

Borge, L.-E. (2005). Strong politicians, small deficits: evidence from norwegian local governments. European Journal of Political Economy 21(2), 325 - 344.

Brender, A. and A. Drazen (2008). How do budget deficits and economic growth affect reelection prospects? evidence from a large panel of countries. American Economic Review 98(5), 2203-2220.

Bretschneider, S. and W. Gorr (1992). Economic, organizational, and political influences on biases in forecasting state sales tax receipts. International Journal of Forecasting 7(4), 457-466.

Bretschneider, S. I., W. L. Gorr, G. Grizzle, and E. Klay (1989). Political and organizational influences on the accuracy of forecasting state government revenues. International Journal of Forecasting 5(4), 307-319.

Cameron, A. C., J. B. Gelbach, and D. L. Miller (2011). Robust inference with multiway clustering. Journal of Business \& Economic Statistics 29(2), 238-249.

Campbell, B. and E. Ghysels (1997, August). An empirical analysis of the canadian budget process. Canadian Journal of Economics 30(3), 553-576.

Canova, F. and E. Pappa (2006). The elusive costs and the immaterial gains of fiscal constraints. Journal of Public Economics 90(89), 1391 - 1414.

Cassidy, G., M. Kamlet, and D. Nagin (1989). An empirical examination of bias in revenue forecasts by state governments. International Journal of Forecasting 5(3), 321-331.

Chatagny, F. and N. Soguel (2012). The effect of tax revenue budgeting errors on fiscal balance: evidence from the swiss cantons. International Tax and Public Finance 19, 319-337. 10.1007/s10797-011-9189-5. 
Couture, J. and L. M. Imbeau (2009). Do governments manipulate their revenue forecasts? budget speech and budget outcomes in the canadian provinces. In Do They Walk Like They Talk? Speech and Action in Policy Processes, Studies in Public Choice, Chapter 9, pp. 155-166. Springer.

de Haan, J., J.-E. Sturm, and G. Beekhuis (1999). The weak government thesis: Some new evidence. Public Choice 101(3-4), 163-176.

Debrun, X., L. Moulin, A. Turrini, J. Ayuso-i Casals, and M. S. Kumar (2008). Tied to the mast? national fiscal rules in the european union. Economic Policy 23(54), 297-362.

Deschamps, E. (2004). The impact of institutional change on forecast accuracy: A case study of budget forecasting in washington state. International Journal of Forecasting 20, 647-657.

Feenberg, D. R., W. Gentry, D. Gilroy, and H. S. Rosen (1989). Testing the rationality of state revenue forecasts. The Review of Economics and Statistics 71(2), 300-308.

Feld, L. P., F. Heinemann, A. Kalb, M.-D. Moessinger, and S. Osterloh (2011). Sovereign bond market reactions to fiscal rules and no-bailout clauses - the swiss experience. Mimeo, University of Freiburg.

Feld, L. P. and G. Kirchgaessner (2008). On the effectiveness of debt brakes: The swiss experience. In R. Neck and J.-E. Sturm (Eds.), Sustainability of Public Debt, Chapter 9, pp. 223-255. Cambridge: MIT Press.

Goeminne, S., B. Geys, and C. Smolders (2008). Political fragmentation and projected tax revenues: evidence from flemish municipalities. International Tax and Public Finance 15, 297-315.

Hallerberg, M., R. Strauch, and J. von Hagen (2007). The design of fiscal rules and forms of governance in european union countries. European Journal of Political Economy 23, 338-359.

Hayo, B. and F. Neumeier (2014). Political leaders' socioeconomic background and fiscal performance in germany. European Journal of Political Economy 34(0), $184-205$.

Hibbs, Douglas A., J. (1977). Political parties and macroeconomic policy. The American Political Science Review 71(4), pp. 1467-1487.

Jochimsen, B. and S. Thomasius (2014). The perfect finance minister: Whom to appoint as finance minister to balance the budget. European Journal of Political Economy 34(0), 390 - 408.

Jones, V. D., S. Bretschneider, and W. L. Gorr (1997). Organizational pressures on forecast evaluation: Managerial, political, and procedural influences. Journal of Forecasting 16(4), 241-254.

Ladner, A. (2006). Das schweizer parteiensystem in bewegung. In O. Niedermayer, R. Stss, and M. Haas (Eds.), Die Parteiensysteme Westeuropas. Wiesbaden: VS Verlag fr Sozialwissenschaften.

Luechinger, S. and C. Schaltegger (2013). Fiscal rules, budget deficits and budget projections. International Tax and Public Finance 20(5), 785-807.

Milesi-Ferretti, G. M. (2003). Good, bad or ugly? on the effects of fiscal rules with creative accounting. Journal of Public Economics 88(1-2), 377-394.

Mocan, N. H. and S. Azad (1995). Accuracy and rationality of state general fund revenue forecasts: Evidence from panel data. International Journal of Forecasting 11(3), 417 - 427. 
Moessinger, M.-D. (2014). Do the personal characteristics of finance ministers affect changes in public debt? Public Choice, 1-25.

Ohlsson, H. and A. Vredin (1996). Political cycles and cyclical policies. Scandinavian Journal of Economics 98(2), 203-218.

Paleologou, S.-M. (2005). Political manoeuvrings as sources of measurement errors in forecasts. Journal of Forecasting 24, 311-324.

Perotti, R. and Y. Kontopoulos (2002). Fragmented fiscal policy. Journal of Public Economics 86(2), 191 $-222$.

Persson, T. and G. Tabellini (2000). Political Economics: Explaining Economic Policy. MIT Press.

Pina, I. M. and N. M. Venes (2011). The political economy of edp fiscal forecasts: An empirical assessment. European Journal of Political Economy 27, 534-546.

Poterba, J. M. (1994). State responses to fiscal crises: The effects of budgetary institutions and politics. Journal of Political Economy 102(4), 799-821.

Rogoff, K. (1990, March). Equilibrium political budget cycles. The American Economic Review 80(1), $21-36$.

Rogoff, K. and A. Sibert (1988, January). Elections and macroeconomic policy cycles. The Review of Economic Studies 55(1), 1-16.

Schaltegger, C. A. and L. P. Feld (2009). Do large cabinets favor large governments? evidence on the fiscal commons problem for swiss cantons. Journal of Public Economics 93(12), 35 - 47.

Swank, O. H. (2002, April). Budgetary devices for curbing spending prone ministers and bureaucrats. Public Choice 111(3), 237-257.

Tavares, J. (2004). Does right or left matter? cabinets, credibility and fiscal adjustments. Journal of Public Economics 88(12), 2447-2468.

van der Ploeg, F. (2010). Political economy of prudent budgetary policy. International Tax and Public Finance 17, 295-314. 10.1007/s10797-009-9117-0.

Velasco, A. (2000). Debts and deficits with fragmented fiscal policymaking. Journal of Public Economics $76(1), 105-125$.

Vlaicu, R., M. Verhoeven, F. Grigoli, and Z. Mills (2014). Multiyear budgets and fiscal performance: Panel data evidence. Journal of Public Economics 111(0), 79 - 95.

von Hagen, J. (2010). Sticking to fiscal plans: the role of institutions. Public Choice 144, 487-503.

Voorhees, W. R. (2004). More is better : Consensual forecasting and state revenue forecast error. International Journal of Public Administration 27(8/9), 651-671.

Weingast, B. R., K. A. Shepsle, and C. Johnsen (1981, August). The political economy of benefits and costs: A neoclassical approach to distributive politics. Journal of Political Economy 89(4), 642-664. 


\section{Appendix}

Stringency of Fiscal Rules in Swiss Cantons (1980-2007)

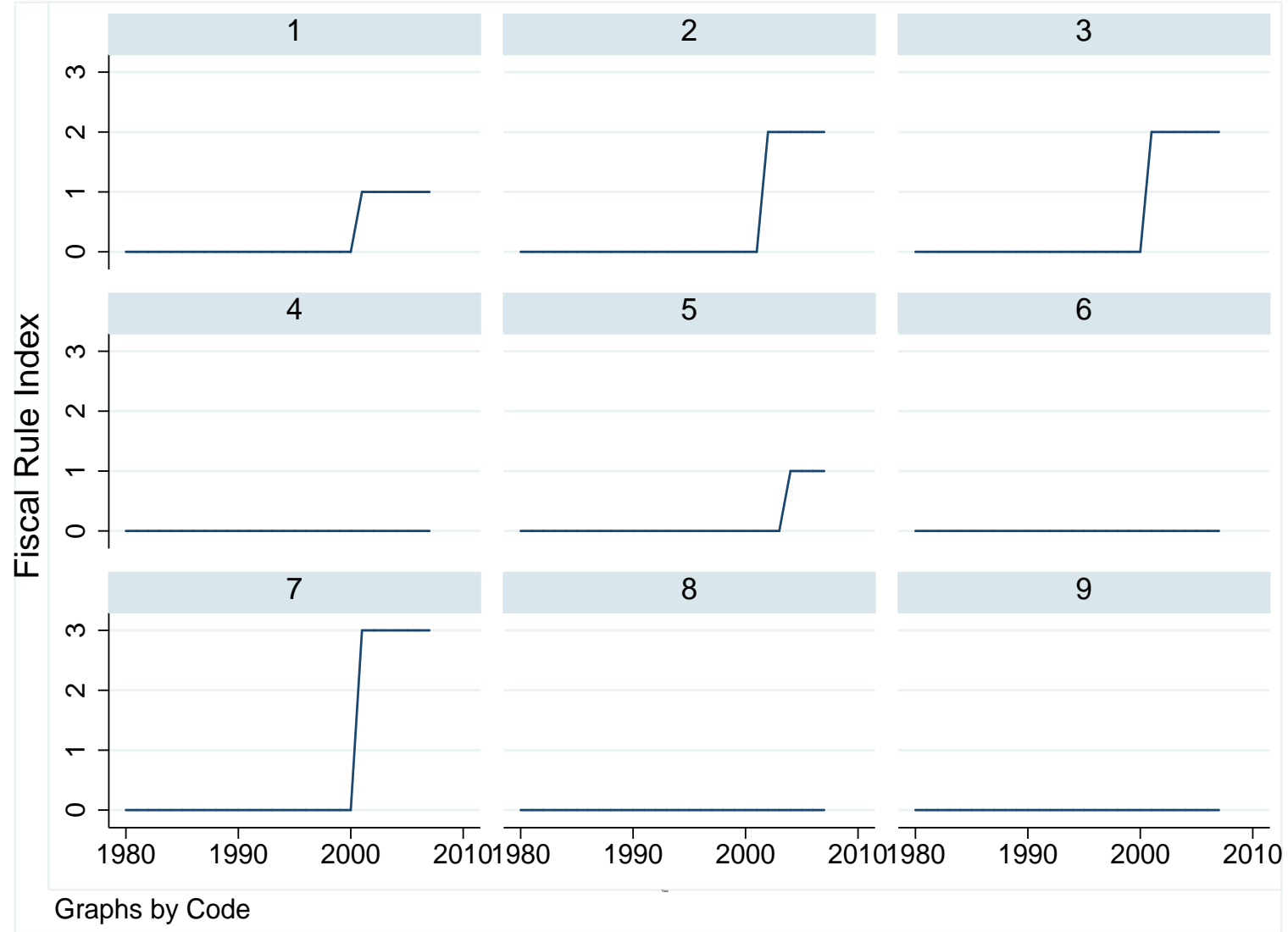




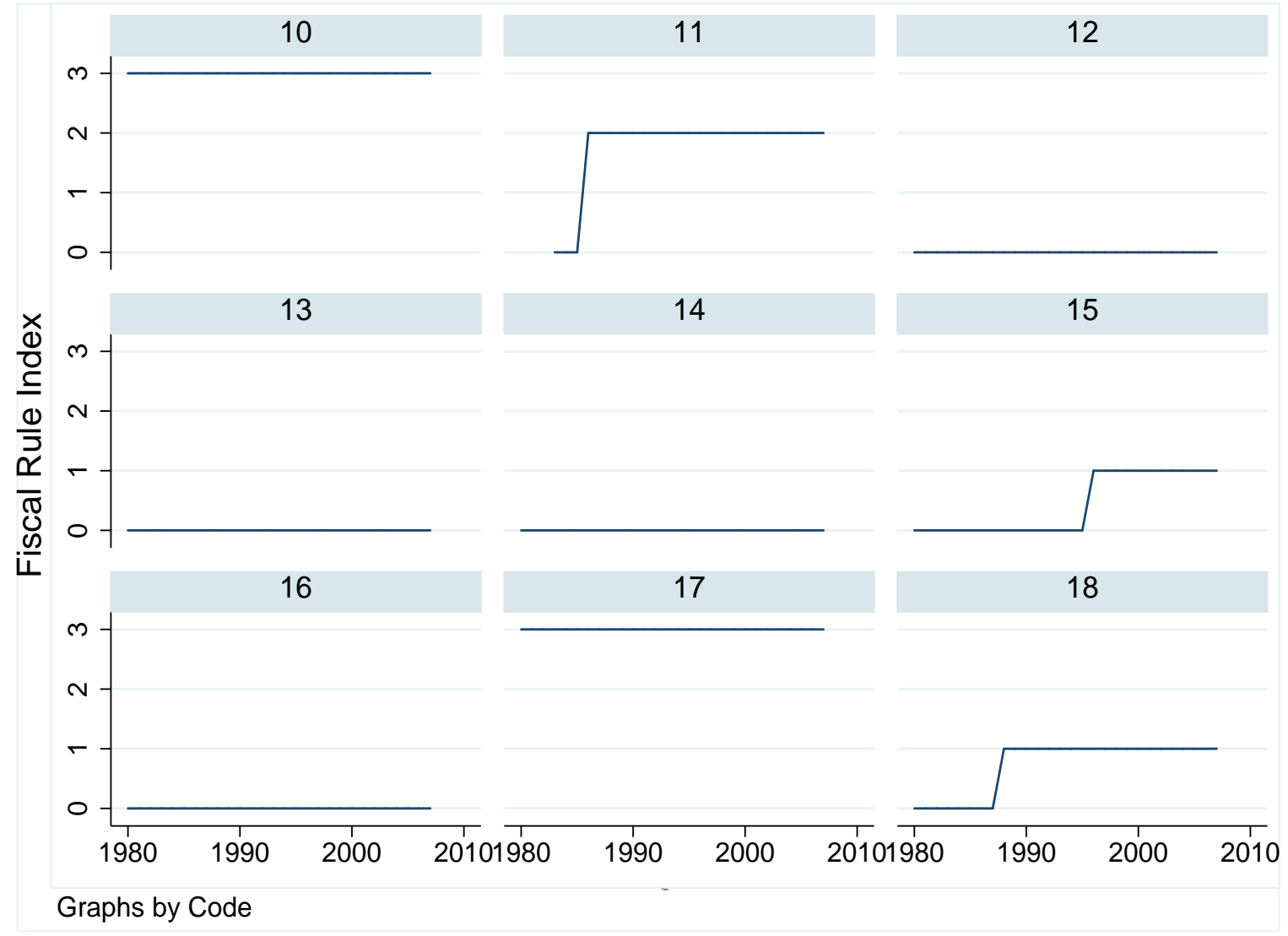




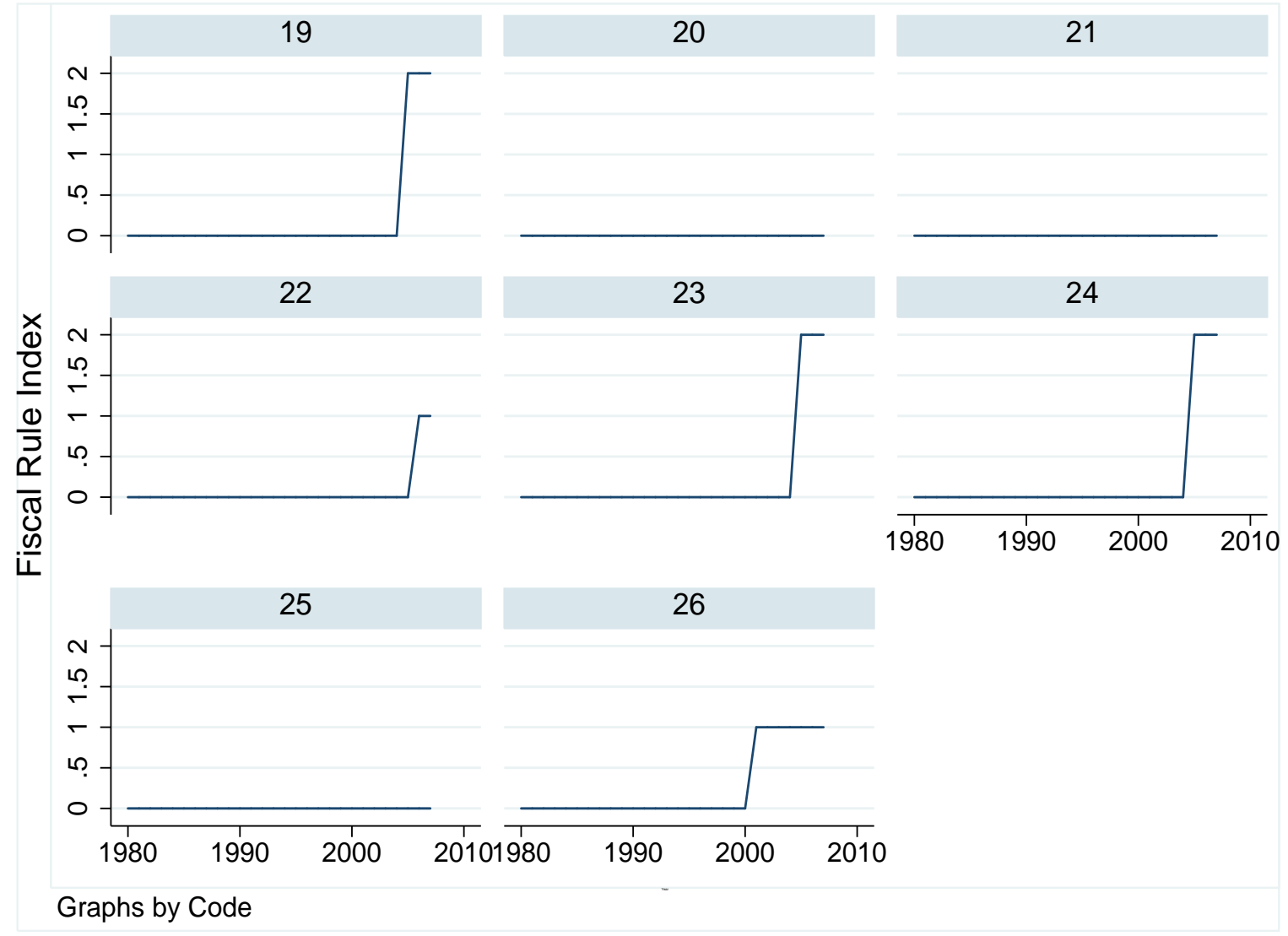


Control variables at the cantonal level

Table .9: Cantonal Controls : Summary Statistics

\begin{tabular}{lccccc}
\hline \hline \multicolumn{1}{c}{ Variable } & Mean & Std. Dev. & Min. & Max. & N \\
\hline Election year & 0.249 & 0.433 & 0 & 1 & 728 \\
Fragmentation & 3.371 & 0.916 & 1 & 5 & 728 \\
Concordance & 85.766 & 10.398 & 53.333 & 100 & 723 \\
Departments & 7.390 & 2.277 & 4 & 13 & 728 \\
Right & 76.534 & 15.182 & 40 & 100 & 728 \\
Postnumerando & 0.276 & 0.447 & 0 & 1 & 728 \\
Grant & 0.718 & 0.66 & 0.074 & 5.915 & 726 \\
Deficit(-1) & -0.091 & 0.506 & -3.027 & 2.832 & 702 \\
Growth & 0.016 & 0.042 & -0.178 & 0.408 & 702 \\
Unemployment(D) & 0.083 & 0.705 & -2.7 & 2.9 & 702 \\
\hline All variables expressed in real terms & & & &
\end{tabular}

All variables expressed in real terms.

Average Marginal Effect of the Finance Minister's Ideology at each Stringency Level of Fiscal Rules

Table .10: Marginal Effect of the Finance Minister's Ideology on TRPE

\begin{tabular}{lcccccc}
\hline Fiscal Rule & $\mathbf{d y} / \mathbf{d x}$ & $\mathbf{S E}$ & $\mathbf{z}$ & $\mathbf{p}-$ value & CI lower bound & CI higher bound \\
\hline \hline 0 & 72.24614 & 8.011281 & 9.02 & 0.0000 & 56.54432 & 87.94796 \\
1 & 61.35202 & 7.127347 & 8.61 & 0.0000 & 47.38268 & 75.32136 \\
2 & 50.4579 & 10.57812 & 4.77 & 0.0000 & 29.72517 & 71.19062 \\
3 & 39.56378 & 15.73127 & 2.51 & 0.0120 & 8.731048 & 70.3965 \\
\hline
\end{tabular}


Table .11: Dynamic Specification of the Model

\begin{tabular}{|c|c|c|c|c|}
\hline & (1) & $(2)$ & (3) & (4) \\
\hline Ideology & $\begin{array}{c}64.91^{* * *} \\
(9.887)\end{array}$ & $\begin{array}{c}69.01^{* * *} \\
(10.27)\end{array}$ & $\begin{array}{c}64.47^{* * *} \\
(18.34)\end{array}$ & $\begin{array}{c}69.82^{* * *} \\
(16.36)\end{array}$ \\
\hline Rule & $\begin{array}{c}57.37 \\
(36.17)\end{array}$ & $\begin{array}{c}58.25 \\
(37.26)\end{array}$ & $\begin{array}{c}43.42 \\
(36.39)\end{array}$ & $\begin{array}{c}51.25 \\
(34.94)\end{array}$ \\
\hline Ideology x Rule & $\begin{array}{l}-10.95^{*} \\
(6.239)\end{array}$ & $\begin{array}{c}-11.07^{*} \\
(6.396)\end{array}$ & $\begin{array}{c}-8.514^{*} \\
(4.812)\end{array}$ & $\begin{array}{c}-11.00^{* *} \\
(5.017)\end{array}$ \\
\hline Pre-election year & $\begin{array}{c}-60.00^{* * *} \\
(16.41)\end{array}$ & $\begin{array}{c}-54.54^{* * *} \\
(16.69)\end{array}$ & $\begin{array}{c}-29.00^{* *} \\
(14.00)\end{array}$ & $\begin{array}{c}-37.59^{* * *} \\
(14.43)\end{array}$ \\
\hline Election year & $\begin{array}{l}-5.329 \\
(16.38)\end{array}$ & $\begin{array}{l}-4.249 \\
(16.57)\end{array}$ & $\begin{array}{l}-4.530 \\
(17.01)\end{array}$ & $\begin{array}{l}-2.203 \\
(16.71)\end{array}$ \\
\hline Post-election year & $\begin{array}{l}-30.87^{*} \\
(16.68)\end{array}$ & $\begin{array}{c}-30.89^{*} \\
(16.89)\end{array}$ & $\begin{array}{l}-20.69 \\
(14.58)\end{array}$ & $\begin{array}{c}-24.46^{*} \\
(14.78)\end{array}$ \\
\hline Error(-1) & $\begin{array}{l}0.415^{* * *} \\
(0.0386)\end{array}$ & $\begin{array}{l}0.403^{* * *} \\
(0.0394)\end{array}$ & $\begin{array}{c}0.282^{* * *} \\
(0.100)\end{array}$ & $\begin{array}{c}0.383^{* * *} \\
(0.0929)\end{array}$ \\
\hline Minister controls & Yes & Yes & Yes & Yes \\
\hline Canton FE & Yes & Yes & Yes & Yes \\
\hline Canton controls & Yes & Yes & Yes & Yes \\
\hline Time FE & Yes & Yes & Yes & Yes \\
\hline Observations & 603 & 603 & 653 & 629 \\
\hline \multicolumn{5}{|c|}{$\begin{array}{l}\text { Standard errors in parentheses } \\
{ }^{*} p<.10,{ }^{* *} p<.05,{ }^{* * *} p<.01\end{array}$} \\
\hline
\end{tabular}

Table .12: Model Including the Ideological Gap

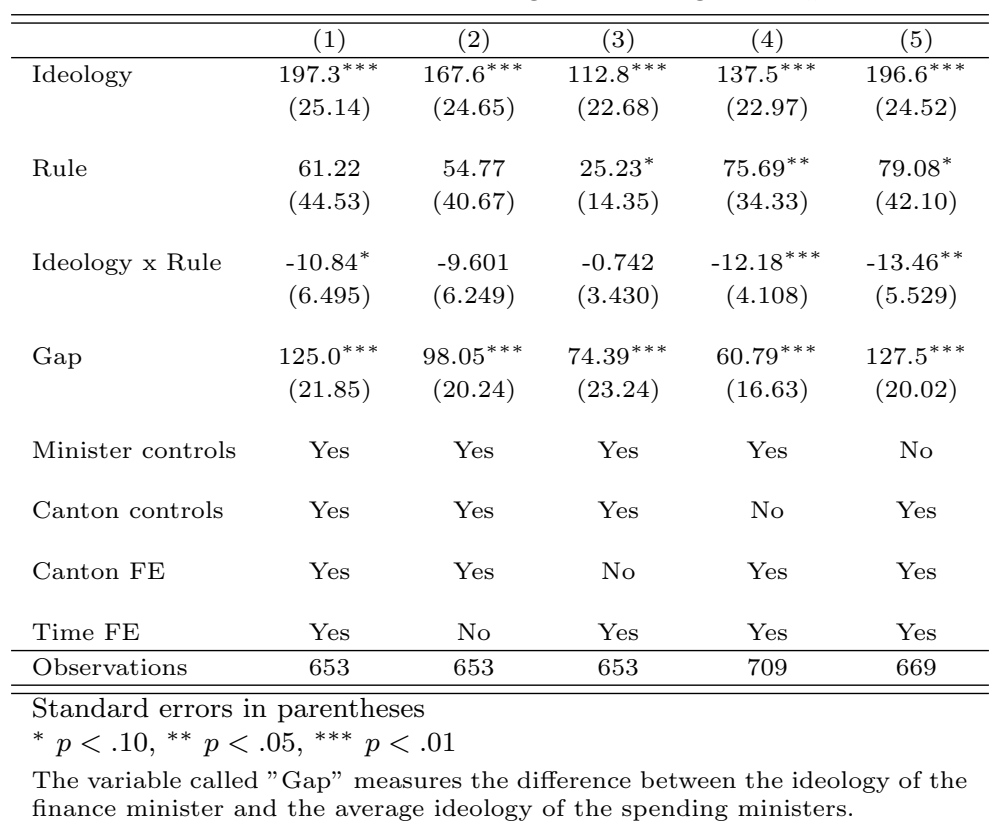

